\title{
Application Of Hypnoteaching Method To Improve Self- Confidence And Results Of Student Mathematic Learning
}

\author{
Febriani Dwi Sari ${ }^{1 *}$, Erlina Prihatnani ${ }^{2}$ \\ 1,2 Student of Departement of Mathematics Education Faculty of Teachin Satya Wacana Christian University
}

A R T I C L E I N F O

Article history:

Received 20 July 2018

Received in revised

form

10 August 2018

Accepted 15 October

2018

Available online 28

November 2018

Keywords:

Hypnoteaching, learning

outcomes, self-

confidencei, PTK, algebra

\begin{abstract}
A B S T R A C T
This research aims to improve student's mathematics learning outcomes and their self-confidence using the Hypnoteaching method on the learning of Algebra for class VIII A of Islam Sultan Fattah Salatiga Junior High School. This research is included as classroom action research. The model used in this research is the Kemmis \& Mc Taggart's which consists of 4 stages namely planning, implementation, observation, and reflection. The improvement of student's learning outcomes and self-confidence in learning mathematics are seen from their grades and self-confidence questionnaire scores. On one hand, 1st cycle of questionnaire results show that student's had experienced improvement in self-confidence by $58 \%$ with the average of student's learning outcomes by $58.4 \%$ and $42 \%$ completeness. On the other hand, the 2nd cycle of questionnaire results show that students had experienced improvement in self-confidence by $79 \%$ with the average of student's learning outcomes by $76.9 \%$ and $79 \%$ completeness
\end{abstract}

Copyright (C) Universitas Pendidikan Ganesha. All rights reserved.

\section{Introduction}

Permendiknas No. 22 of 2006 concerning the Content Standard states that mathematics is a universal science that underlies the development of modern technology. This is what makes mathematics a very important scientific discipline to learn. Through learning mathematics, there are four competencies that need to be applied, as stipulated in Permendiknas Number 21 of 2016 concerning content standards. One of the core competencies that exist is knowledge. Knowledge is used to equip students to have the ability to understand and apply factual knowledgel, conceptual, procedural, and metacognitive at a simple technical and specific level based on the curiosity about science, technology, art, culture with humanity, nationality and state-of-the-art insights related to the phenomena and events that appear to the eye. Knowledge can be measured using learning outcomes. Muhibin Syah (2008: 132) said that knowledge is one of the factors that influence learning outcomes.

Learning outcomes are the results achieved in the form of numbers or scores after being given a test of learning outcomes at the end of each lesson (Dimyati and Mudjiono, 2013). According to Sudjana (2005: 22), learning outcomes are abilities possessed by students after receiving learning experiences.

The fact is that not all learning outcomes, especially on math subject, are good. Based on Final $r$ Semester Evaluation data on mathematics class VIII A at Sultan Fattah Islamic Middle School in Salatiga, only 8 students achieved mastery. The average results of the Final Semester Evaluation on mathematics class VIII A also only reached 68.4 (below the KKM of 70) with a completeness level of $42 \%$ (below the criteria for completeness limit of $70 \%$ ).

Based on these results, observations were made on the learning process of class VIII A mathematics at Sultan Fattah Islamic Middle School Salatiga. The observation results showed that students are less interested in mathematics subject. This is seen when the teacher delivered the material not all students paid attention. Some students actually played and chatted with friends. Some students also did not want to record the material explained by the teacher. During learning, students were less active in learning. 
In addition to these problems, during interviews, 15 of 21 students said that they could not learn mathematics. Mathematics for most students is difficult and impossible to master. The results of the recapitulation of the self-confidence questionnaire filled by students also showed the same thing. As much as $75 \%$ of students are still classified as not confident. Self-confidence is an aspect that is expected to be achieved by students, as regulated in the core competency of social attitudes in Permendikbud Number 21 Year 2016. Students are expected to be able to respect and live honest, disciplined, responsible, caring, polite, and confident behavior. .

Rakhmat (Hendriana, 2017:198) defined self confidence as a belief in oneself that each individual has in his life, and how the individual sees himself by referring to self-concept. As for Lauser (Hendriana, 2017: 197) defined self-confidence as an attitude or feeling of confidence in one's own abilities so that the person concerned is not too anxious in his actions, able to feel free to do things he likes, and is responsible for his actions, warm and polite in interacting with others, can accept and respect other people, have an urge to excel and recognize their strengths and weaknesses.

Yates (Hendriana, 2017:198) explained that self-confidence is very important for students to succeed in learning mathematics. With the existence of self-confidence, students will be more motivated and prefer to learn mathematics thus in the end it is expected that mathematics learning achievement achieved is more optimal. Research by Mullis and Rakmad, (Hendriana, 2017: 198) revealed that there is a positive association between self-confidence in learning mathematics and learning outcomes in mathematics. Therefore, students need self-confidence to optimize learning outcomes. Unfortunately, not all students have confidence in learning mathematics.

One effort that can be done to overcome the problem of low learning outcomes and also the confidence of class VIII A Sultan Fattah Islamic Middle School Salatiga is by choosing the right learning model. One of them is by applying a method that not only emphasizes the improvement of learning outcomes but also can foster student confidence. One of them is by applying the Hypnoteaching method.

Hypnoteaching is a learning method that in delivering material, teachers use subconscious languages that can foster their own interest in students (Yustisia, 2016: 75). In line with the statement of Yustisia, Navis (2013: 128) stated that Hypnoteaching is learning that involves the conscious mind with the subconscious mind. Hypnoteaching is a combination of two words, hypnosis and teaching. Hypnosis means giving and teaching which means teaching. So, it can be interpreted that Hypnoteaching is an attempt to hypnotize or suggest students to be better and their performance increases.

The steps of the Hypnoteaching method according to Noer (Yustisia: 2016: 85) included intention and motivation in self, pacing (equating position with other people or students), leading (leading or directing), using positive words, giving praise, modeling or set an example, and mastery of the material by the teacher. In addition, Noer (2010: 137-144) also mentioned several things that can support the implementation of Hypnoteaching, namely, teacher appearance, empathic attitude, sympathy, use of language, visual (for kinesthetic), student motivation with stories or stories, and teacher's skills in capturing the students' hearts.

Hypnoteaching has several advantages including 1) the teaching-learning process is more dynamic and there is good interaction between the teacher and students, 2) learning is active, 3) students are more able to imagine and think creatively, 4) students will learn happily, and 5) students can easily master the material because they are more motivated to learn (Hajar, 2011: 82-83). In addition, the research conducted by As'ari (2018) stated that the advantages of the Hypnoteaching method are 1) the activities of the teaching and learning process occur better because of the good interaction, 2) The learning process is more active because it uses motor movements of the body, 3) Students more easily master the material, 4) Students are more motivated to learn, 5) Students can think imaginatively and creatively, and 6) Students' attention is more focused on the material. ) This is in line with Braid (1860) who said that the advantages of learning by using Hypnoteaching are that the process is more dynamic and there is good interaction between educators and students.

Hypnoteaching can change students' perceptions of teachers who teach, namely to assume that teachers are their protector thus they create a familiar and pleasant learning atmosphere that makes it easier for students to absorb and understand lessons (Hajar, 2011: 80). This is in line with De Vos \& Louw (2008) which stated that hypnosis mental training programs are applied to students, able to change students 'self-concepts so that they can improve students' academic abilities. The benchmark for the effectiveness of teaching and learning activities in schools is indicated by a pleasant atmosphere and students are able to understand the lesson to the fullest.

There is research using the Hypnoteaching method including research conducted by Kasmaja (2017), (Eline Yanty Putri Nasution, 2015), and Nurul Awalina et al (2016). In a study conducted by Kasmaja (2017) concluded that the learning of the Hypnoteaching method is quite effective to be applied in order to improve mathematics learning outcomes on the subject of quadrilateral flat building and can 
increase student learning motivation. In addition, by applying the Hypnoteaching method, it can increase student learning motivation. The research conducted by Nasution (2015) concluded that Hypnoteaching learning technique can overcome students' learning difficulties while being able to improve the mathematics learning outcomes of the subject matter of a two-variable linear equation system. There are also studies that examined the influence of Hypnoteaching on self-confidence. The research conducted by Nurul Awaliana, et al (2016) by showing that applying the Visual Auditory Kinesthetic (VAK) model with the Hypnoteaching technique resulted in an increase in students' self-confidence in demonstrating drama characters.

There needs to be a follow-up effort to overcome the problem of the low self-confidence students have and the problem of the students' low mathematics learning outcomes. One effort that can be done is to apply a model that cannot only improve learning outcomes but also methods that can foster students' confidence, namely the Hypnoteaching method. This method is applied in mathematics learning in algebraic material. This research is expected to add insight into the knowledge of the Hypnoteaching method and inspire readers to apply the Hypnoteaching method in the process of learning mathematics.

\section{Method}

This research is a follow-up of problems found in the learning process in the classroom. Therefore this study includes classroom action research (CAR). PTK model used is the Kemmis and Mc Taggart model which consists of four stages, namely planning, implementation, observation, and reflection.

This research was conducted in class VIII A of Sultan Fattah Islamic Middle School Salatiga, having its address at Jalan Diponegoro 115 Siderejo Lor, Sidorejo, Salatiga City 50714. The research was conducted in February 2018 until October 2018. The time for learning began from July 23, 2018 until August 21, 2018 with a total of 10 meetings. The subjects in this study were class VIII A Sultan Fattah Salatiga Islamic Middle School in total of 19 students, 10 male students and 9 female students. This research was carried out in cycles that stopped if it had reached the success indicator, namely the student test scores reached the specified KKM of 70, the class average had increased and the grade completeness was at least $75 \%$. As for the results of filling in the self-confidence questionnaire students reached a minimum percentage score of $75 \%$.

Data colleciton technique used in this research included documentation, observation, questionnaire, and test techniques. Documentation method in this research was used to obtain the results of mathematics scores acquisition before being given action (pre-cycle value). Observation method was used to collect data about the implementation of learning and using teacher observation sheets and student observation sheets. The questionnaire method was used to measure student confidence. Student confidence questionnaire consists of 4 (four) types of indicators including believing in one's own abilities, acting independently in making decisions, having a positive self-concept, and daring to express opinions. The scale used in the questionnaire method was Likert scale which consisted of 5 scales, namely very agree, agree, neutral, disagree, and strongly disagree. The test method used to measure student learning outcomes after being given an action with a test instrument in the form of a description question.

Data that has been obtained, was analyzed by descriptive quantitative and qualitative descriptive data analysis techniques. Quantitative descriptive was used to analyze scores on student learning outcomes, student self-confidence questionnaire scores and recapitulation of scores from observations of teacher and student activities. While qualitative descriptive was used in categorizing scores generated on quantitative data.

\section{Results and Discussion}

\section{Pre Cycle}

The researcher recapitulated the results of the eighth grade learning of Sultan Fattah Islamic Middle School. The results of the recapitulation showed that the average learning outcomes of class VIII A amounting to 68.42 with the completeness achieved as much as $42 \%$ thus it has not yet reached the predetermined indicator of success which amounts to 70 and also the grade completeness at least $75 \%$. The recapitulation of the results of filling in the self-confidence questionnaire showed that $75 \%$ of students fall into the category of not confident in learning mathematics.

\section{Cycle 1 \\ Action Plan}

This study used the Hypnoteaching method, where the teacher used emotional hours in the learning process as a way to train students' emotions. The results of the discussion with the teacher on the 
application of the Hypnoteaching method were carried out on algebraic material. This material was conveyed by using a variety of learning strategies including matching cards to determine similar tribes, quiz contests in addition and subtraction of algebraic forms, group games using lotteries such as NHT model (Numbered Head Together) on algebraic multiplication and algebraic form distribution, and paired discussions such as TSTS (Two Stay Two Stray) model on material simplify the algebraic form.

\section{Action Implementation}

The implementation phase of the action is the implementation of the planning that has been designed before. The researcher acted as a teacher, while the mathematics teacher of class VIII A acted as an observer. The action in the first cycle is divided into 6 meetings. The following is a description of the meetings.

a. Initial Activity

The learning activities in each cycle refer to Permendiknas number 22 of 2016 which begins with preparing students psychologically and physically, providing contextual benefits, giving questions as a bridge to the previous material, conveying learning objectives and conveying material and activities to be carried out. Each distinguishing meeting is to prepare students psychologically, namely the first meeting of the teacher to display the video TOMAT (Please, Sorry, Thank You) as a means of giving examples, learning videos from ducks that teach about realizing and appreciating that each person's abilities are different, and paralympic videos describing limitations does not hinder achievement. All of the videos are of means to present aspects of Modeling, Pacing, and Leading in learning.

Where in the second meeting, the application of Hypnoteaching is done in the form of giving miraculous questions while at the third meeting the teacher gave Pacing and Leading in presenting a video about the dangers of smoking. Images of people with colored hair like punk kids and soccer players at the fourth meeting are modeled forms that give an example that is not a style that is valued but someone's performance that makes the person cool. The meeting of the five forms of Pacing and Leading is carried out by the teacher by presenting videos about ideals. While at the sixth meeting the teachers used miracle questions as one of the steps to implementing Hypnoteaching.

Not only is it different in preparing students, the learning objectives at the training meeting are different and this has an impact on the different strategies of learning activities as well. The learning objectives in the first, second to sixth meeting in a row are understanding the terms of coefficients, variables, constants, and similar terms, completing the addition and subtraction of algebraic forms through quiz competitions, solving algebraic multiplication problems through group games, completing algebraic form distribution and at the sixth meeting conducted an evaluation by giving the posttest end of cycle 1 .

b. Core Activity

The learning process always uses emotional hours at each meeting. Learning activities in the first meeting, second to sixth meeting are matching cards, quiz competitions, group games using plano paper, odd even games, and replays. To support these activities the student worksheets are distributed that have been compiled by including Hypnoteaching elements such as giving motivational words. At the core activity the teacher also applies the form of Hypnoteaching such as teaching and praising when group activities, giving appreciation and positive words and modeling or modeling when learning activities take place.

c. Closing Activity

At each meeting, there are 4 (four) activities carried out repeatedly at each meeting. The four activities are a reflection of the activities that have been carried out and an understanding of the material that has been studied, giving feedback, planning follow-up, and providing information for the next meeting.

\section{Observation}

Observations carried out during the learning process take place which consists of observation of learning by the teacher and observation of student responses. The results of the recapitulation of filling the teacher observation sheet can be seen in Table 1. 
Table 1. Results of Recapitulation of Teacher Activity Observation Sheet of Cycle 1

\begin{tabular}{llll}
\hline No & Aspects Observed & Percentage & Category \\
\hline 1. & Suitability of the implementation of learning with the & $84,63 \%$ & Very good \\
& standard KTSP process & & \\
2. & Suitability of learning with the Hypnoteaching method. & $84,72 \%$ & Very good \\
3. & The ability of teachers in classroom management. & $84,09 \%$ & Very good \\
4. & The teacher's ability to master the material. & $75,00 \%$ & Good \\
\hline
\end{tabular}

In addition to observing the implementation of learning by the teacher, there are observations of student activities. The recapitulation of the results of filling out the student observation sheet can be seen in Table 2.

Table 2. Results of Recapitulation of Students Observation Sheet Activity of Cycle 1

\begin{tabular}{llll}
\hline No & Aspects Observed & Percentage & Category \\
\hline 1. & Discipline & $77,43 \%$ & Good \\
2. & Activeness & $71,59 \%$ & Good \\
3. & Focus on learning & $73,70 \%$ & Good \\
4. & Responsibility for assignments & $82,75 \%$ & Very good \\
\hline
\end{tabular}

In cycle 1 also obtained data on learning outcomes. The acquisition of individual scores can be seen in Figure 1, while the recapitulation of learning outcomes in cycle 1 can be seen in Table 3.

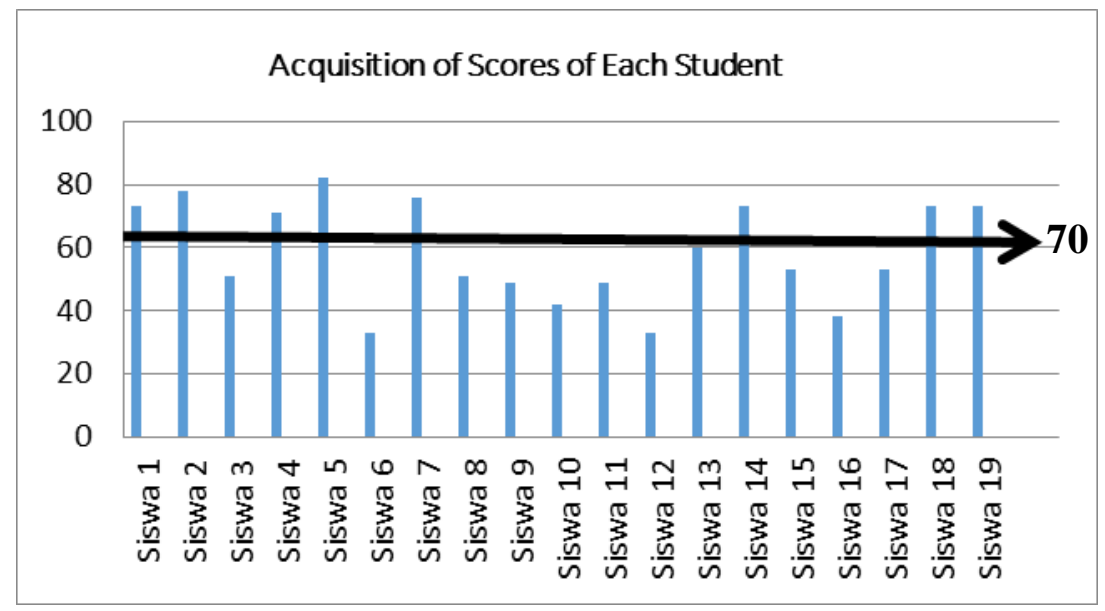

Figure 1 Chart of Scores Acquisition of Each Student in Cycle 1

Table 3.Learsning Results Cycle 1

\begin{tabular}{|c|c|c|c|c|c|c|c|}
\hline \multirow[t]{2}{*}{ Total Student } & \multirow[t]{2}{*}{$\begin{array}{l}\text { Highest } \\
\text { Score }\end{array}$} & \multirow[t]{2}{*}{$\begin{array}{l}\text { Lowest } \\
\text { Score }\end{array}$} & \multirow{2}{*}{$\begin{array}{l}\text { Class } \\
\text { Average } \\
\text { Score }\end{array}$} & \multicolumn{2}{|c|}{$\begin{array}{l}\text { Student } \\
\text { Completed }\end{array}$} & \multicolumn{2}{|c|}{$\begin{array}{l}\text { Student } \\
\text { Incompleted }\end{array}$} \\
\hline & & & & Total & Percentage & Total & Percentage \\
\hline 19 & 82 & 33 & 58,4 & 8 & $42 \%$ & 11 & $58 \%$ \\
\hline
\end{tabular}

In Table 3 it can be seen that cycle 1 produces a class average of 58.4 with completeness which is still low at $42 \%$. The percentage of completeness obtained by students class VIII A has not reached the standard of completeness as much as $75 \%$, as well as the class average score has not yet reached standard completeness score which amounts to 70. In addition to learning outcomes, in the first cycle the student questionnaire was filled in. The results of filling out the questionnaire at the end of cycle 1 can be seen in Figure 2. 


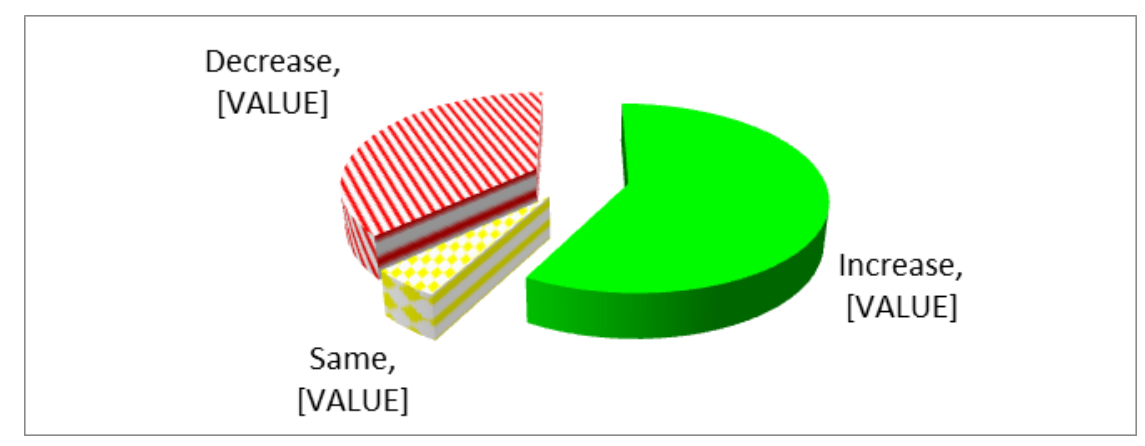

Figure 2 Comparison of Categories of Students with Low, Moderate, and High Self-Confidence Levels

\section{Cycle 2}

\section{Action Planning}

Action planning in cycle 2 is done by compiling learning scenarios that pay attention to deficiencies in cycle 1 . This is used to correct each meeting in cycle 2 .

\section{Action Implementation}

As in cycle 1 , the implementation phase is carried out after the action planning stage. The action in cycle 2 is divided into 4 meetings. The following is a description of the four meetings.

a. Initial Activity

The initial activity in cycle 2 is the same as cycle 1 which consists of 5 (five) activities. In cycle 2 , which distinguishes each of them, namely when giving motivation. Giving motivation at the first meeting is by showing a video about peer tutoring, this is also a form of modeling or example. The motivation for the second meeting is carried out by the teacher by providing a reference in the form of rewards that will be given to the three students who got the highest score, which can increase the value most, and whose name is on the student's reward posters during learning. The third meeting of the teacher presented a video about a mother's struggle which was also a form of Pacing and Leading. While at the fourth meeting the teacher reminded about the reward obtained as a form of student motivation before working on posttest 2 .

In addition to giving the motivation that distinguishes each meeting is the learning goal. The learning objectives in the first meeting to the fourth meeting in a row are to simplify the addition and subtraction of algebraic fractions, simplify the fraction of algebraic forms, simplify the division of fractions of algebraic forms and carry out posttest 2 .

b. Core Activity

The strategy used by the teacher in cycle 2 is to implement paired discussions as in the TSTS model (Two Stay Two Stray). This is also supported by student worksheets that have been prepared in accordance with the TSTS model. The learning process also takes place by using emotional clocks in each of its activities. At each activity the teacher also gives appreciation and positive words to students as a form of Hypnoteaching application.

c. Closing Activity

As in cycle 1, cycle 2 also has 4 (four) activities carried out repeatedly at each meeting. The four activities are to reflect on the activities that have been carried out and the material that has been studied, provide feedback, plan follow-up, and provide information for the next meeting.

\section{Observation}

Observations in cycle 2 also consist of observations of learning by teachers and student activities. The results of the recapitulation of observations of learning by teachers in cycle 2 can be seen in Table 4 .

Table 4. Results of Recapitulation of Teacher Activity Observation Sheet Cycle 2

\begin{tabular}{|c|c|c|c|}
\hline No & Aspects Observed & Percentage & Category \\
\hline 1. & $\begin{array}{l}\text { Suitability of the implementation of learning with the } \\
\text { standard KTSP process }\end{array}$ & $87,35 \%$ & Very good \\
\hline 2. & Suitability of learning with the Hypnoteaching method. & $86,11 \%$ & good \\
\hline 3. & The ability of teachers in classroom management. & $86,36 \%$ & Very good \\
\hline 4. & The teacher's ability to master the material. & $75,00 \%$ & Good \\
\hline
\end{tabular}


As for the recapitulation of the results of filling out the student observation sheet can be seen in Table 5. The following are the results of the recapitulation of the results of filling out the student observation sheet.

Table 5. Results of Recapitulation of Student Activity Observation Sheet Cycle 2

\begin{tabular}{llll}
\hline No & Aspects Observed & Percentage & Category \\
\hline 1. & Discipline & $78,07 \%$ & Good \\
2. & Activeness & $80,70 \%$ & Very good \\
3. & Focus on learning & $80,70 \%$ & Very good \\
4. & Responsibility for assignments & $87,72 \%$ & Very good \\
\hline
\end{tabular}

In addition to observational data, cycle 2 also obtained data on learning outcomes. The acquisition of individual scores can be seen in Figure 3, while the recapitulation of learning outcomes in cycle 2 can be seen in Table 6.

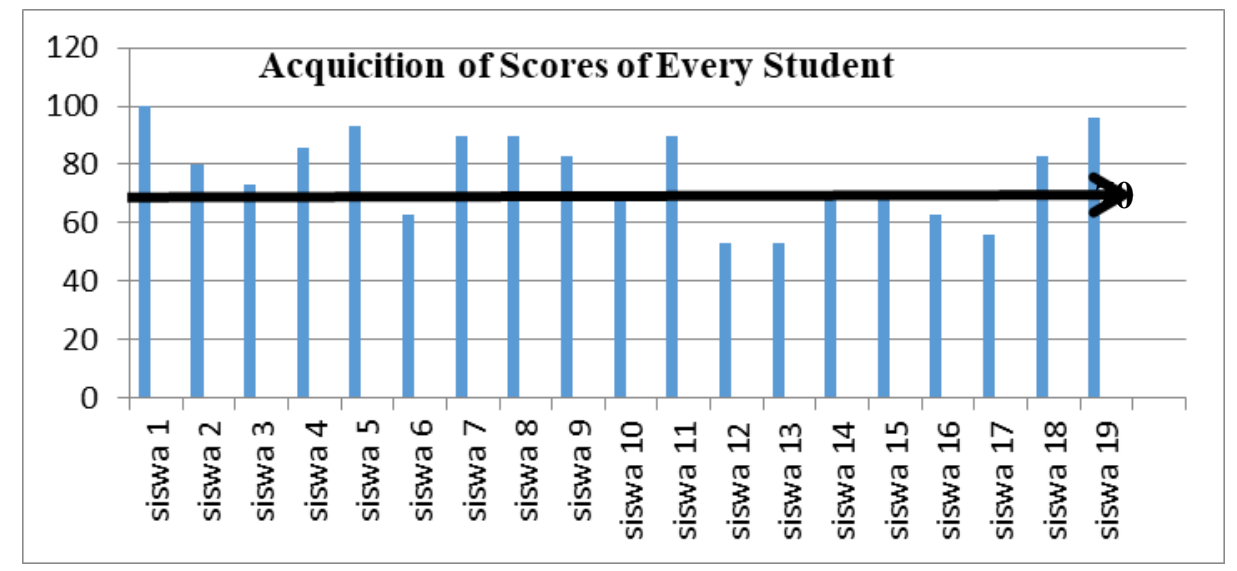

Figure 3 Chart of Scores Acquisition of Every Student Cycle 2

Table 6.Learning Results Cycle 2

\begin{tabular}{|c|c|c|c|c|c|c|c|}
\hline \multirow[t]{2}{*}{$\begin{array}{l}\text { Total } \\
\text { Student }\end{array}$} & \multirow[t]{2}{*}{$\begin{array}{l}\text { Highest } \\
\text { Score }\end{array}$} & \multirow[t]{2}{*}{$\begin{array}{l}\text { Lowest } \\
\text { Score }\end{array}$} & \multirow{2}{*}{$\begin{array}{l}\text { Class } \\
\text { Average } \\
\text { Score }\end{array}$} & \multicolumn{2}{|c|}{$\begin{array}{l}\text { Student } \\
\text { Completed }\end{array}$} & \multicolumn{2}{|c|}{$\begin{array}{l}\text { Student } \\
\text { Incompleted }\end{array}$} \\
\hline & & & & Total & Percentage & Total & Percentage \\
\hline 19 & 100 & 53 & 76,9 & 15 & $79 \%$ & 4 & $21 \%$ \\
\hline
\end{tabular}

Filling in the student self-confidence questionnaire in learning mathematics is also given after the final test of cycle 2. Comparison of the results of the questionnaire filling in the posttest can be seen in Figure 4.

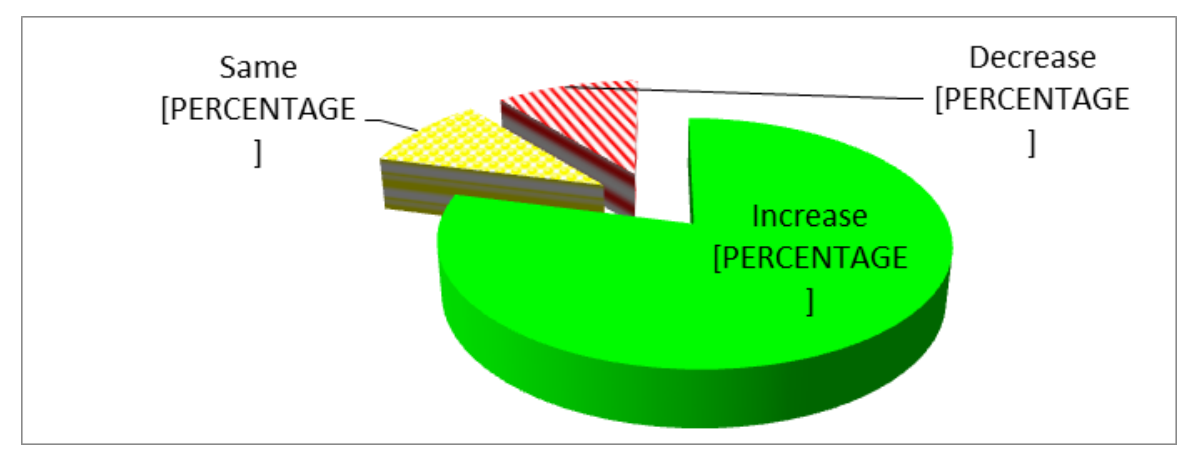

Figure 4 Comparison of Categories of Students with Low, Moderate, and High Self-Confidence Levels 


\section{Description Among Cycles}

Learning outcomes from both actions have a significant increase from cycle 1 to cycle 2 . Based on the results of the analysis in cycle 1 and cycle 2, a comparison can be made. Comparison of learning outcomes in cycle 1 with cycle 2 can be seen in Table 7.

Table 7. Comparison of Cycle 1 and Cycle 2 Learning Outcomes

\begin{tabular}{|c|c|c|c|c|c|c|c|c|}
\hline \multirow{2}{*}{ Cycles } & \multirow{2}{*}{$\begin{array}{l}\text { Total } \\
\text { Studen } \\
t\end{array}$} & \multirow{2}{*}{$\begin{array}{l}\text { Highest } \\
\text { Sore }\end{array}$} & \multirow{2}{*}{$\begin{array}{l}\text { Lowest } \\
\text { Score }\end{array}$} & \multirow{2}{*}{$\begin{array}{l}\text { Class } \\
\text { Average } \\
\text { Score }\end{array}$} & \multicolumn{2}{|c|}{$\begin{array}{l}\text { Student } \\
\text { Completed }\end{array}$} & \multicolumn{2}{|c|}{$\begin{array}{l}\text { Student Who } \\
\text { Incompleted }\end{array}$} \\
\hline & & & & & Total & $\begin{array}{l}\text { Percentag } \\
\mathrm{e}\end{array}$ & Total & $\begin{array}{l}\text { Percent } \\
\text { age }\end{array}$ \\
\hline Cycle 1 & 19 & 82 & 33 & 58,4 & 8 & $42 \%$ & 11 & $58 \%$ \\
\hline Cycle 2 & 19 & 100 & 53 & 76,9 & 15 & $79 \%$ & 4 & $21 \%$ \\
\hline
\end{tabular}

In addition to learning outcomes, after the application of the Hypnoteaching method the results of filling in the student self-confidence questionnaire in learning mathematics in cycle 1 and cycle 2 of students class VIII A Sultan Fattah Islamic Middle School Salatiga can be compared. The comparison of students' confidence in cycle 1 and cycle 2 can be seen in Figure 5.

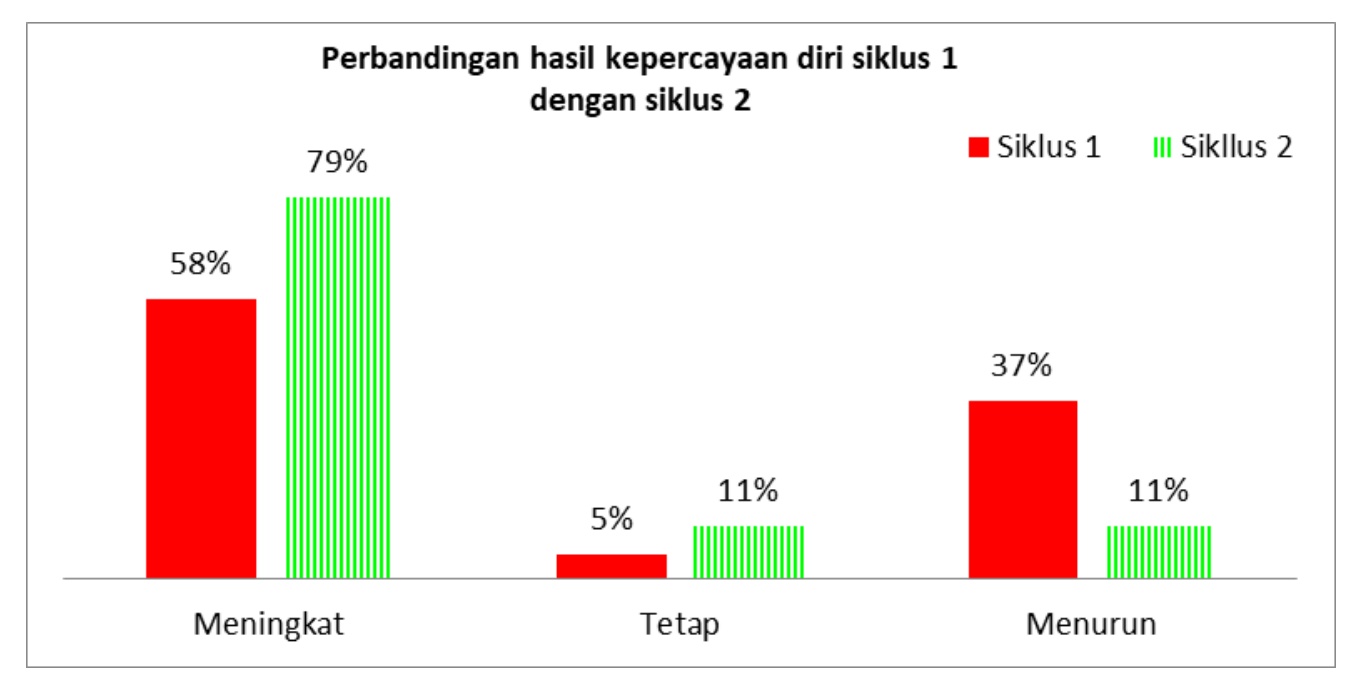

Figure 5. Comparison of results of self-confidence cycle 1 with cycle 2

The initial conditions of the research subject experienced problems with low learning outcomes, because students were less enthusiastic, lacked participation and were less interested in mathematics. In addition to the problems of learning outcomes, there were problems with self-confidence. This can be seen in the results of the questionnaire filling in the recapitulation which shows $75 \%$ of students is still classified as low. Referring to these two problems, learning was done by applying the Hypnoteaching method.

Cycle 1 covers action planning, implementation of actions, and observations. In Table 1, it can be seen that the implementation of learning which includes the activities or actions of teachers in the initial, core and closing activities in learning has been designed and implemented very well. Learning was carried out in accordance with the Hypnoteaching method, and there was a very good management of classes, which means that the learning process is conducive. Mastery of the material by the teacher falls into the good category. This is because the teacher seemed to have difficulties in conveying concepts on contextual problems in algebraic forms. In addition to the results of observations of teacher activities, there were observations of student activities in Table 2 . The data in Table 2 shows that in cycle 1 the responsibility for assignments is included in the excellent category. This is because the students in working on the task were diligent. But for discipline, activity and focus in learning, it is still included in the good category. The reason is that the condition of the class was crowded thus student attention is not fully on the learning material and students also have not been daring to ask about the material unclear for them.

The crowded conditions of the class and students who have not been brave enough to ask questions caused the students' learning outcomes to be not optimal. Learning outcomes in cycle 1 can be seen in 
Table 3. Percentage of class completeness only reached $42 \%$. In addition, the results of filling out the questionnaire also showed that the number of students whose self-confidence increased by $58 \%$, students who had self-confidence remained at $5 \%$, and students whose self-confidence decreased by $37 \%$. These results have not yet reached the indicators of the success of students' self-confidence in learning mathematics that have been determined in this study that is equal to $75 \%$ of students in the classroom can increase their confidence in learning mathematics.

Based on the results of the implementation of the learning activities in cycle 1 , a reflection of all activities that have been carried out is carried out. Through observations made, the researcher obtained several advantages and disadvantages that need to be corrected in the next cycle.

Strengths in cycle 1 include learning design challenges, preparation of Lesson Plan, and compilation of worksheets that are good for exploring students' abilities and in accordance with the Hypnoteaching method. In addition, some students have been active in discussing, working on worksheets, and students are honest in doing the tests.

Lack in cycle of 1 among them the teacher seemed to have difficulties in delivering concepts on contextual problems in the form of algebra, the allocation of time was not good, so the closing activities were not well implemented, not optimal in applying the Hypnoteaching method. This can be seen in one of the meetings where there was a little debate between teachers and students at the time of learning, students were less active in asking questions to teachers, so many students did not understand the subject matter, teacher skills in managing the discussion were lacking, students were dissatisfied of the way the teacher divided the class group because they felt they were not suitable for heterogeneous group members, and the distribution of rewards to students was less well implemented. Therefore it is necessary to do cycle 2 .

Deficiencies in cycle 1 were used to improve each meeting in cycle 2 such as emphasizing delivery in the form of material concepts, paying more attention to time allocation, improving teacher intentions and motivation in applying the Hypnoteaching method, considering sharing groups well, and looking for more effective learning strategies. As with cycle 1, in cycle 2 there were also planning actions, implementing actions, and observing. In Table 4 it can be seen that the aspects of the teacher's ability to master the material are included in the good category. The other three aspects are the suitability of the implementation of learning with the standard KTSP process, the suitability of learning with the Hypnoteaching method, and the ability of teachers in class management to be included in the excellent category. In addition, the results of observations on student activities are shown in Table 5.

The data in Table 5 shows that in cycle 2 the overall activity of students is classified as very good. This can be seen in the percentage of aspects of activeness, focus in learning, and responsibility for tasks. However, in the disciplinary aspect it is not yet categorized as very good, this is because some students had several problems before learning, such as student mobile phones taken by the teacher, and student ties cut by the teacher because they were full of scribbles.

Learning outcomes in cycle 2 show that the average class is 76.9 with completeness reaching $79 \%$. The percentage of completeness in cycle 2 has reached a set standard of completeness that is equal to $75 \%$ and the average obtained has also reached standard completeness set by Sultan Fattah Islamic Middle School Salatiga which amounts to 70 . In addition, the results of filling in the questionnaire also indicate that the number of students whom their confidence increased by $79 \%$, students who had self-confidence remained at $10 \%$ and students whose confidence decreased by $11 \%$. In addition to what happened, the percentage increased from cycle 1 to cycle 2. The results have reached the indicators of success of students' self-confidence in learning mathematics that has been determined in this study that is equal to $75 \%$ of students fall into the category of high self-confidence.

After completing the learning improvement activities in cycle 2 and observing the learning actions, the results of the observations show that students were more actively asking questions, student selfconfidence has been seen during the learning process in the classroom, and students were enthusiastic in learning. This can be seen when students were given a question on the board, most students seemed active working and dare to go forward working on the board without having to be told by the teacher. This second cycle has been declared successful because it has reached the three predetermined indicators of success.

The results of the comparison of the initial scores of cycle 1 and cycle 2, there was an increase in the class average from 58.4 to 76.9 with completeness which also increased which was from $42 \%$ to $79 \%$. The completeness percentage of students class VIII A achieved in cycle 1 to cycle 2 has reached the specified standard, that is, at least $75 \%$ of students completed the standard completeness, and the class average score has also reached the determined standard completeness which amounts to 70 . In line with the comparison of student learning outcomes, on the comparison of the results of filling in students' selfconfidence questionnaires also showed an increase in the results of confidence in students of students 
class VIII A Sultan Fattah Islamic Middle School Salatiga. In Cycle 1 students whose self-confidence increased by $58 \%$, students who had self-confidence remained at $5 \%$, and which decreased by $37 \%$. While in cycle 2 , students whose self-confidence increased by $79 \%$, students who had self-confidence remained at $11 \%$, and which decreased by $11 \%$.

Based on the findings above, it can be concluded that the Hypnoteaching method can improve mathematics learning outcomes and students' confidence in mathematics. In addition, the results obtained have met the performance indicators in this study, namely $75 \%$ both on student learning outcomes and student self-confidence, so the implementation of learning was stopped in cycle 2.

These findings prove that the importance of choosing the right learning method in carrying out teaching and learning activities. This is in line with the findings of other researchers such as the research conducted by Rahmawatiningrum (2012) and Prasmala (2014) showing that the Hypnoteaching method can improve students' mathematics learning outcomes. As well as findings found in the research conducted by Prabawanti (2017) which showed that the Hypnoteaching method can increase students' confidence. Based on the results of this study, by applying the Hypnoteaching method can improve learning outcomes and students' confidence in learning mathematics.

\section{Conclusions and Suggestions}

This study aims to improve learning outcomes and to increase students' self-confidence through the Hypnoteaching method in algebraic form of students class VIII A Sultan Fattah Islamic Middle School Salatiga. Based on the results of research conducted at Sultan Fattah Islamic Middle School in Salatiga with students class VIII A students, it can be concluded that the application of the Hypnoteaching method can improve learning outcomes and students' confidence in learning mathematics in class VIII A Sultan Fattah Islamic Middle School Salatiga in algebraic material.

The average student learning outcomes in cycle 1 are 58.4 (have not reached standard of completeness) and have increased to 76.9 in cycle 2 . On average these have reached the specified standard of completeness of 70 . In addition, the percentage of class completeness in cycle 1 is $42 \%$ and in cycle 2 as much as $79 \%$. The percentage of completeness has only reached the indicator of success $(75 \%)$ in cycle 2 . Both of these results indicate that the application of the Hypnoteaching method can improve the mathematics learning outcomes of students class VIII A Sultan Fattah Islamic Middle School.

As for the aspect of self-confidence, as much as $58 \%$ of students experienced an increase in selfconfidence from pre-cycle to cycle 1 and the percentage of students who experienced increased selfconfidence from cycle 1 to cycle 2, up to 79\%. This percentage in cycle 2 has reached the minimum percentage score on the success indicator, which is $75 \%$. Based on these results, it can be concluded that the application of the Hypnoteaching method can increase the confidence of students class VIII A Sultan Fattah Islamic Middle School in learning mathematics.

This study has shown that the Hypnoteaching method can improve learning outcomes and students' confidence in learning mathematics. Therefore it is recommended to the teacher to be able to read various references about the Hypnoteaching method and can apply it to create a conducive learning atmosphere and can suggest students to learn so that it can foster students' confidence in learning and can produce better learning outcomes. This study has provided empirical data on how a good suggestion can provide more learning outcomes and self-confidence, so that students can be as much as possible to think positively so that they can suggest themselves to always be sure they can give the best.

\section{Refferences}

As'ari, K. (2018). UPAYA MENINGKATKAN HASIL BELAJAR PENDIDIKAN AGAMA ISLAM (PAI) MENGGUNAKAN METODE HYPNOTEACHING BAGI SISWA KELAS VII C SMPN 1 LIMBANGAN KABUPATEN KENDAL TAHUN 2016/2017 As'ari, Kasan. Al-Fikri: Jurnal Studi Dan Penelitian Pendidikan Islam, Vol 1(No 1). https://doi.org/10.1074/jbc.M109.064931

Awalina, Nurul, DKK. 2016. Penerapan Model Visual Auditory Kinesthetic (VAK), dengan Teknik Hypnoteaching Untuk Meningkatkan Keterampilan Siswa Memerankan Tokoh Drama Di Kelas V SDN Tegalendah Kecamatan Rancakalong Kabupaten Sumedang. Jurnal Pena Ilmiah: Vol. 1, No. 1.

Braid, Lamp. (2015). The Adventages Hypnoteaching in Teaching. Retrieved on April, 12

De Vos, H. H. \& Louw, D. A. (2008). Hypnosis-Induced Mental Training Programmes as A Strategy to Improv The Self-Concept of Student. Higher Educationn : the international journal of higher 
educaction planning, 57 (2): 141-154. Diperoleh dari https://eric.ed.gov/?id=EJ824893 pada tanggal 20 Juni 2018

Dimyati \& Mudjiono. 2006. Belajar dan Pembelajaran. Jakarta: Rineka Cipta.

Dimyati dan Mudjiono. 2013. Belajar dan Pembelajaran. Cetakan kelima. Rineka Cipta: Jakarta.

Eline Yanty Putri Nasution, M. P. (2015). UPAYA MENINGKATKAN HASIL BELAJAR SISWA DENGAN MENGGUNAKAN TEKNIK PEMBELAJARAN HYPNOTEACHING Oleh: Eline Yanty Putri Nasution, M.Pd 1, 3, 78-95.

Hajar, Ibnu. 2011. Hypnoteaching Memaksimalkan Hasil Proses Belajar-mengajar dengan Hypnoterapi. Jogjakarta: Diva Press.

Hendriana, Heris. 2017. Hardskills dan Softskills matematik siswa. Bandung: Rifeka Aditama.

Kasmaja, Hadi. 2016. Efektivitas Implementasi Metode Hypnoteaching Untuk Meningkatkan Motivasi Dan Hasil Belajar Matematika Pada Siswa SMP Negeri. Journal of EST: Volume 2 Nomor 1 April 2016 hal. 33-45.

Muhibin Syah. 2008. Psikologi Pendidikan dengan Pendekatan Baru. Bandung: Remaja Rosdakarya

Navis, Ali Akbar. 2013. Hypnoteaching Revolusi Gaya Mengajar untuk Melejitkan Prestasi Siswa. Yogyakarta: Ar Ruzz Media.

Noer, Muhammad. 2010. Hypnoteaching for Success Learning. Yogyakarta: Pustaka Instan Mandani.

Prasmala, Erfitra Rezqi. 2014. Penerapan Model Reading Map Group Investigation (GI) untuk Meningkatkan Minat Baca, Kemampuan Berpikir Kritis, Kesadaran Metakognitif dan Hasil Belajar Biologi Siswa Kelas X SMA Surya Buana Malang. Tesis. Jurusan Pendidikan Biologi, Program Pascasarjana Universitas Negeri Malang.

Permendiknas Nomor 21 Tahun 2006

Permendiknas Nomor 21 Tahun 2016

Permendiknas Nomor 22 Tahun 2016

Rabawanti, Reika Widya (2017) Analisis Penggunaan Metode Hypnoteaching Dalam Kegiatan Ekstrakurikuler Seni Tari Remo Di SDN Dampit 01 Kabupaten Malang Tahun Ajaran 2016/2017. Thesis, University of Muhammadiyah Malang.

Rahmawatiningrum, Linta. (2012). Efektivitas Penggunaan Metode Hypnoteaching dalam Pembelajaran Matematika Kelas IV Semester II di SDIP H. Soebandi Kecamatan Bawen Kabupaten Semarang Tahun Pelajaran 2011/2012. Diakses pada Respository UKSW, http://repository.uksw.edu/handle/123456789/845

Sudjana, Nana. 2005. Penilaian Hasil Belajar Mengajar. Bandung: PT Remaja Rosdakarya Offset.

Yustitia, N. 2014. Hypnoteaching. Jogjakarta: Ar-Ruzz Media. 